\title{
The Fine Structure of Bacillus fastidiosus
}

\author{
By E. R. LEADBETTER AND S. C. HOLT \\ Departments of Biology, Amherst College, and Microbiology, \\ University of Massachusetts, Amherst, Mass., U.S.A.
}

(Accepted for publication 12 January 1968)

SUMMARY

Bacillus fastidiosus, an aerobic spore-forming bacterium able to utilize uric acid or allantoin as sole source of carbon and nitrogen, has been re-isolated and its fine structure described. Anatomical features of vegetative cells are similar to those of other members of the genus Bacillus. The mature endospore has typical core and cortical regions. The spore coat is highly laminated and surrounded by a tight-fitting exosporium to which conspicuous exosporial hairs are attached.

\section{INTRODUCTION}

Den Dooren de Jong (1929) isolated and described an aerobic spore-forming bacterium able to utilize an unusually limited range of substrates for growth. Reflected in its name, Bacillus fastidiosus, is its inability to utilize common sugars, amino acids, peptones, etc., as growth substrates; of the wide variety of organic compounds tested, only uric acid and allantoin were so utilized. Also recognized were the hair-like or rhizoidal extensions of colonies which, although not so pronounced as those of $B$. mycoides, were quite distinctive.

Although Bacillus fastidiosus was a well-described and recognized Bacillus in the 5th edition of Bergey's Manual of Determinative Bacteriology, more recent editions either relegate this organism to an uncertain status (6th edition) or do not even recognize its existence (7th edition). This change undoubtedly reflects, albeit incorrectly, the results of Smith, Gordon \& Clark's (1952) comparative study of Bacillus species in which $B$. fastidiosus was not listed as an organism extensively studied and classified. These investigators clearly recognized that the culture received by them under the name $B$. fastidiosus 'bore no resemblance to the original organism' as described by den Dooren de Jong.

This paper reports the re-isolation of Bacillus fastidiosus and an examination of its fine structure.

\section{METHODS}

Isolation. The organism studied was isolated from Florida Everglades soil by enrichment culture in a medium containing $\mathrm{I} \cdot 0 \%(\mathrm{w} / \mathrm{v})$ uric acid and $0 . \mathrm{I} \%(\mathrm{w} / \mathrm{v})$ $\mathrm{K}_{2} \mathrm{HPO}_{4}$ in distilled water. Approximately $0.2 \mathrm{~g}$. soil was added to $50 \mathrm{ml}$. of this medium in a $250 \mathrm{ml}$. Erlenmeyer flask; incubation was at $30^{\circ}$ on a reciprocating shaker. After $48 \mathrm{hr}$ incubation, a small sample of the enrichment culture was pasteurized at $80^{\circ}$ for $15 \mathrm{~min}$. and then plated on to the same medium solidified with $2 \%(\mathrm{w} / \mathrm{v})$ Bacto-agar. A small portion of a well-isolated colony which appeared after 4 days 
incubation was emulsified, pasteurized, and replated to obtain a pure culture. Additional strains were isolated from a variety of other soil samples.

Growth. In addition to growth on solid medium, the organism was also grown in liquid, using biphasic conditions. One hundred $\mathrm{ml}$. of $2 \%(\mathrm{w} / \mathrm{v})$ Bacto-agar in disstilled water was allowed to solidify on the bottom of a $I 1$. Erlenmeyer flask. One hundred $\mathrm{ml}$. uric acid-agar medium was then added aseptically. This was allowed to solidify and then $200 \mathrm{ml}$. uric acid (0.I \%, w/v) $-\mathrm{K}_{2} \mathrm{HPO}_{4}(0 . \mathrm{I} \%$, w/v) broth was aseptically added. All cultures were incubated at $30^{\circ}$; biphasic cultures were aerated by shaking on a reciprocating shaker.

Phase-contrast microscopy. Both plate-grown and biphasic cultures were used for phase-contrast microscopy; cells grown on solid medium were scraped from the surface and dispersed in distilled water; cells from liquid biphasic cultures were examined directly. Samples for light photomicroscopy were layered on agar-coated glass slides, covered with coverslips and photographed with a Zeiss GFL phase-contrast photomicroscope, using Adox KB-I4 photographic film.

Electron microscopy. Samples for electron microscopy were fixed in osmium tetroxide ( $1 \%$, w/v), embedded in Epon 812 (Holt \& Leadbetter, 1967), and thin sections stained with lead hydroxide (Karnovsky, I96I).

For phosphotungstic acid (PTA) negative staining, I \% or $3 \%$ PTA (adjusted to pH 6.85 with $\mathrm{NaOH}$ pellets) was used. Samples were either diluted with the stain until faintly turbid and then placed on 300-mesh carbon-coated grids, or stained on the grids.

Shadow casting was performed in a Denton DV-502 vacuum evaporator. The sample to be shadowed was placed on 300-mesh carbon-coated grids, dried for $60 \mathrm{~min}$., and shadowed with platinum-carbon at an angle of $30^{\circ}$ at a distance of $8 \mathrm{~cm}$. Carbon replicas were prepared by the procedure of Holt \& Canale-Parola (1967). All samples for electron microscopy were examined in a Phillips EM-200 electron microscope operating at $60 \mathrm{kV}$., equipped with either a Io or $30 \mu$ objective aperture. Contamination of the specimen was avoided by employing a liquid nitrogen cold finger at the level of the specimen.

\section{RESULTS}

Organism. The organisms which grew on uric acid + agar medium appeared identical to those observed by den Dooren de Jong (1929), as judged by their distinctive colonial characteristics, the size and shape of spores and vegetative cells, motility, dissolution of uric acid, and inability to grow on a variety of other carbon or carbon and nitrogen sources, including complex media such as yeast extract and nutrient agar. The one apparent difference between den Dooren de Jong's isolate and ours was in the Gram reaction; young, motile cells of our isolate were Gram-positive. Den Dooren de Jong's report of Gram-negative cells may reflect the physiological age of the cells examined.

Cultures growing on uric acid liberated ammonia, with a concomitant rise in $\mathrm{pH}$ to between 8 and 9. Attempts to obtain growth at $\mathrm{pH} 8.0$ and 8.5 on phosphate-buffered complex media containing $\mathrm{NH}_{4} \mathrm{Cl}$, but lacking uric acid, were unsuccessful.

Phase-contrast microscopy. The vegetative bacilli of Bacillus fastidiosus are long rods, about $5 \mu \times \mathrm{I} \cdot 5 \mu$ (PI. I, fig. I). The cytoplasm is uniform in appearance, indicating the absence of a multinucleate condition or visible storage material. The spores 
of $B$. fastidiosus are highly refractile structures (Pl. I, fig. 2), $3 \mu \times \mathrm{I} \cdot 5 \mu$, and are predominantly ellipsoidal, although a few tend toward a nearly spherical shape (Pl. I, figs. 2, 3). The prespores are located in an essentially terminal position within the mother cell.

Flagella. Growth in liquid culture was dispersed, and the chains of cells that predominate on agar medium were rarely found. Motility was readily observed only in very young cultures; when biphasic cultures reached densities greater than $10^{8}$ cells $/ \mathrm{ml}$., or when organisms were grown on solid medium for more than $24 \mathrm{hr}$, very few bacilli appeared motile. Occasionally, when young vegetative bacilli were examined by light microscopy, a helical structure approx. $0.4 \mu$ diam. could be detected on one side of non-motile vegetative organisms or could be seen lying free in the microscopic field. Electron microscopic examination of such cultures after negative staining revealed these helical structures to be bunches or aggregates of flagella (Pl. I, fig. 4; P1. 2, fig. 5).

Flagella were arranged peritrichously on vegetative bacilli and each flagellum was c. $0.02 \mu$ in diam. As seen in P1. 2, fig. 5, the flagella terminated in a typical 'hook' (Abram, Koffler \& Vatter, 1965; Abram, Vatter \& Koffler, 1966).

The cell wall had a mesh-like or woven fine structure similar to that reported for other bacteria (Salton, 1964) (P1. 2, figs. 6, 7).

Cell surface. As judged by shadowed preparations, the vegetative bacillus surface was smooth and the organism rather flat (Pl. 3, fig. 9), while the spore surface (Pl. 4 , fig. I0) was quite irregular and threw a very long shadow, thus indicating that it had considerable height. The cell wall fine structure seen in negatively stained preparations was not visible.

Treatment with chromic acid after shadowing and carbon deposition (replication) caused the vegetative bacilli and spores to lose their opacity, owing to the dissolution and extrusion of cellular contents. After this treatment, it became possible to observe on replicas taken from vegetative bacilli (Pl. 4, fig. II) a textured surface similar to that observed in both sectioned and negatively stained cells (Pl. 2, fig. 5-7; Pl. 3, fig. 8). Again, replicas revealed the contrast between the regular surface of the vegetative bacillus and the multiple ridges and irregularities of the spore surface ( $\mathrm{Pl}$. 4, fig. I2). The fine structure observed on the vegetative bacillus surface was not seen in the spore integument. The spore surface, including terminal knobs, appeared similar to that reported by Fitz-James \& Young (1959) and Lechtman, Bartholomew, Phillips \& Russo (1965).

\section{Vegetative organisms}

\section{Electron microscopy of thin sections}

The vegetative bacilli of Bacillus fastidiosus were encased in what appeared to be a typical Gram-positive cell wall (PI. 5, fig. 13-I6), approx. $500 \AA$ in width. The border of the cell has a regular shape. Although they are both clearly defined in Pl. 5, fig. I3, and P1. 6, fig. 17, it was often difficult to observe a demarcation between the cell wall and the plasma membrane, probably because of adhesion of the plasma membrane to the innermost layer of the wall. This adhesion of cell wall and plasma membrane was suggested by Mitchell \& Moyle (1956) to be characteristic of Gram-positive bacteria. The cell wall appeared slightly more dense than the enclosed cytoplasm. This difference in density may reflect a difference in chemical composition, may depend on the capability of the fixative (osmic acid) to penetrate into the cytoplasm through the cell 
wall (where it may accumulate) or may depend on the quantity of ribonucleoprotein in the cytoplasm (Edwards \& Stevens, 1963). Adsorption, on the wall, of material of foreign origin sometimes gave the wall an irregular shape (P1. 5, fig. I3) (Glauert, 1962).

The multi-layered wall (Pl. 5, fig. 13; Pl. 6, fig. I7) had dense outer and inner layers, about 120 and $250 \AA$ in thickness, and a middle layer, of lower density, about I $80 \AA$ thick. This middle component varied in width and was not always clearly observed. In P1. 5, fig. I4, the cell wall was separated from the plasma membrane by a I $20 \AA$ space of low density, and possible cross-bridging (Edwards \& Stevens, I963; Ghosh \& Murray, 1967) between the cell wall and the outer portion of the plasma membrane can be observed.

\section{Plasma membrane}

Where the plasma membrane was clearly defined, it showed typical unit membrane structure (Robertson, I959), with a total thickness of 60-75 $\AA$ (Pl. 5, fig. I4, I5). In some portions of the membrane, the outer and inner layers appeared to have the same thickness but this was not evident in many sections because of the similar density of the inner layer and adjacent cytoplasm.

\section{Intracytoplasmic membranes}

A system of membranes, variable in size and shape, are located in the cytoplasm of Bacillus fastidiosus. These mesosomes (Fitz-James, 1960) or plasmalemmosomes (Edwards \& Stevens, 1963) appeared (Pl. 5, figs. 14, I6) to be developed by intrusions of the plasma membrane, as has already been established by many workers, although their attachment to the plasma membrane was not always seen in the plane of sectioning. They may be simple invaginations or complex organelles of various appearances (P1. 5, fig. 14-16).

\section{Cytoplasm}

The cytoplasm of Bacillus fastidiosus vegetative cells is packed with small granules, approx. I $20 \AA$ in diam. and are here referred to as ribosomes. The cytoplasm appeared free of other inclusions, usually conspicuous in Bacillus, such as metaphosphate, lipid or glycogen bodies.

\section{Nuclear apparatus}

The nuclear apparatus of vegetative bacilli of Bacillus fastidiosus shows the same general features as that found in other bacteria. The nuclear region, which had a lower density than the surrounding cytoplasm and contained fine fibrils, was found either dispersed (Pl. 5, fig. I4) or localized in one central region of the bacillus (Pl. 5, fig. 15).

\section{Spores}

The ultrastructural changes accompanying spore formation in Bacillus fastidiosus appeared rather similar to those observed in other Bacillus species (Fitz-James, 1960; Ellar \& Lundgren, 1966).

The spore is formed directly within the vegetative mother cell and at a specific position. In Pl. 5, fig. I6, and Pl. 7, fig. 19, prespores can be seen at the cell pole. The double forespore membranes, each $50 \AA$ thick, are separated by a $15 \AA$ single mem- 
brane component which, however, does not appear to have typical 'unit structure'. The forespore membranes appeared structurally similar to, and continuous with, the plasma membrane of the vegetative bacillus. Elements of plasmalemmosome structure still appeared attached to the plasma membrane (PI. 5, fig. I6). The nuclear material appeared diffuse and fibrous in this prespore condition.

In later stages in spore formation (Pl. 6, fig. 17, I8), an inner membrane surrounds the diffuse spore core, while the developing electron transparent cortex is bordered by an outer membrane. A highly membranous spore coat developing outside the outer membrane and the beginning of an exosporium, partially surrounding the prespore, was also observed. In a transverse section of a still later stage ( $\mathrm{Pl}$. 7, fig. 20), an accentuated cortex, and what appears to be a completed spore coat and exosporium, could be seen. The diffuse, densely staining areas surrounding the exosporium may be developing exosporial hairs (Gerhardt \& Ribi, 1964) and may connect with the electron dense vegetative wall (sporangium).

After spore liberation, the highly complex nature of this sporangial wall became apparent, possibly because of the loss of intracellular materials (Pl. 8, fig. 21, 22). This structure, $650 \AA$ thick, may be the vegetative wall with the plasma membrane attached by transverse bridges (see Discussion).

The free, mature spore had a diffuse spore core and accentuated cortex (Pl. 9, fig. 23), a highly developed spore coat completely surrounding the cortical region, and a well-developed exosporium with an outer covering of exosporial hairs.

The high magnification micrograph (Pl. 9, fig. 24) shows a portion of the complex spore coat. Some layers of the membranous outer spore coat completely enclose the cortical region, while exterior layers form rather regular projections at intervals of $0.62 \mu$. At each of these apices or ridges, the separation of the membranes is apparent where they enclose an electron dense material which appears tubular in cross section. The ridge between the outer spore coat and exosporium is filled with a heavily staining ground substance. The multi-layered exosporium is cross-bridged (Pl. 6, fig. I7: Pl. 9, fig. 24) and its fine structure appears similar to that of the vegetative cell wall (P1. 6, fig. 17 ; P1. 8, fig. 2I), observations which are consistent with the fine structural similarities of the exosporium (Gerhardt \& Ribi, 1964) and the cell wall (Pl. 2, fig. 6) as seen in negatively stained preparations.

\section{DISCUSSION}

The ultrastructural components of Bacillus fastidiosus spores are not markedly different from those found in various other bacterial endospores. Rarely, however, has examination of spore fine structure revealed, in a given bacterial species, the variety and arrangement of ultrastructural features observed here.

The outer exosporial surface seen (Young \& Fitz-James, 1962) in Bacillus cereus var. alesti has been described as a nap or hair-like projection in $B$. cereus strain TERMINALIS (Gerhardt, \& Ribi, 1964), in B. anthracis (Hachisuka, Kojima \& Sato, 1966), and probably exists in $B$. subtilis (Giesbrecht, 1964). This feature of the exosporium is clearly visible in free endospores of $B$. fastidiosus, although there are only faint indications of its presence on spores not yet released from the sporangium. Underneath this nap the exosporium has a lamellar structure similar to that reported in the exosporial 'basal membrane' in B. cereus strain TERMINALIs (Gerhardt \& Ribi, I964). In 
contrast, another strain of $B$. cereus (Ellar \& Lundgren, I966) has only a single dense layer visible in the exosporium of spores still within the sporangium.

The apices or projections formed by the laminated outer spore coat are similar to those in Bacillus megaterium 350 (Robinow, 1960). The distinct spines or ridges in B. polymyxa (Holbert, I960) and Bacillus sp. strain 636 (Warth, Ohye \& Murrell, 1963), however, did not seem to be formed by such an outer coat. Both the inner and outer spore coats of $B$. fastidiosus appear to be more highly laminated structures than did those of $B$. megaterium 350 (Robinow, 1960) and B. cereus (Ellar \& Lundgren, 1966) and considerably different from those of $B$. coagulans and strain 636 where, although the inner spore coat was highly laminate, the outer coat was uniformly electron-opaque (Warth et al. 1963).

The position and striking structural similarity of the spore coats of Bacillus fastidiosus and the so-called parasporal inclusion bodies reported in $B$. cereus strain TERMINALIS and $B$. anthracis (Gerhardt \& Ribi, I964; Hachisuka, Kojima \& Sato, 1966) suggests to us that these 'bodies' are not discontinuous entities but may represent, in fact, portions of otherwise unpreserved or disrupted coat components. The term parasporal bodies refers to inclusions formed 'alongside the spore' (Hannay, 1956) and not within it. Obviously, then, a different term for the intra-spore structures should be used if our interpretation of their nature proves incorrect.

Robinow's (1960) observation that 'spores of different species of bacteria... differ in the degree of elaboration of their outer envelopes' is again confirmed by this study, for the areas inside the spore coats of Bacillus fastidiosus appear indistinguishable from their counterparts in other species. It is difficult to ascertain critically the extent to which the surface structures of $B$. fastidiosus endospores are identical to or different from those of other aerobic species, for an extensive comparative study of spore ultrastructure is not available. Although it is, then, somewhat hazardous to attempt to relate $B$. fastidiosus to one or another group of aerobic spore-formers on morphological considerations, we believe that the presence of a rather tight-fitting exosporium and reasonably prominent apices or spines indicates a closer relationship to $B$. megaterium than to, for example, $B$. cereus.

Apart from considerations of spore ultrastructure, one additional feature of especial interest relates to the ultrastructure of the Gram-positive cell wall and plasma membrane as seen in Bacillus fastidiosus. We believe that the structure in Pl. 8, fig. 2 I and 22, is the vegetative cell wall and attached plasma membrane from which some chemical components may have been removed as a result of lysis accompanying spore liberation and by extraction during the fixing and dehydration preparations for electron microscopy. The dimensions and the position of the components of the 'emptied' structure agree well with those of the wall-membrane complex of the vegetative cell (P1. 5, fig. 13-16). The bridging seen between the plasma membrane and the cell wall of $B$. fastidiosus is not localized in one specific region of the cell. It thus differs from the localized membrane-to-membrane bridging in the polar regions of Spirillum serpens (Murray \& Birch-Anderson, 1963) but may be similar to the wall-membrane bridging reported in Listeria monocytogenes (Edwards \& Stevens, 1963; Ghosh \& Murray, 1967).

This work was supported by grants from Amherst College and the National Institutes of Health (AI 03459 and GM-14635) and a Special Postdoctoral Fellowship to E. R. 
Leadbetter from the National Institute of Allergy and Infectious Diseases. We wish to thank Mrs Betsy Augusta and Mrs Theresa Stokes for technical assistance.

\section{REFERENCES}

Abram, D., Koffler, H. \& VATTER, A. E. (1965). Basal structure and attachment of fiagella in cells of Proteus vulgaris. J. Bact. 90, 1337.

Abram, D., VATTER, A. E. \& Koffler, H. (1966). Attachment and structural features of flagella of certain bacilli. J. Bact. 9r, 2045.

DEN Dooren DE Jong, L. E. (I929). Ưber Bacillus fastidiosus. Zentbl. Bakt. ParasitKde (2. Abt.) 79, 344.

EDWARDS, M. R. \& STEVEns, R. W. (1963). Fine structure of Listeria monocytogenes. J. Bact. 86, 4 I4.

ELLAR, D. J. \& LundGren, D. G. (1966). Fine structure of sporulation in Bacillus cereus grown in a chemically defined medium. J. Bact. $92,1748$.

Fitz-James, P. C. (1960). Participation of the cytoplasmic membrane in the growth and spore formation of bacilli. J. biophys. biochem. Cytol. 84, 104.

Frtz-JAmes, P. C. \& Young, I. E. (1959). Cytological comparison of spores of different strains of Bacillus megaterium. J. Bact. 78, 755.

GERHARDT, P. \& RIBI, E. (I964). Ultrastructure of the exosporium enveloping spores of Bacillus cereus. J. Bact. 88, I774.

Ghosh, B. K. \& MurRay, R. G. E. (1967). Fine structure of Listeria monocytogenes in relation to protoplast formation. J. Bact. 93, $4 \mathrm{I}$ I.

GiesBRECHT, P. (1964). Über Oberflächenstrukturen von Sporen der Gattung Bacillus. Naturwissenschaften 51, 46.

GlaUERT, A. M. (1962). Fine structure of bacteria. Br. med. Bull. 18, 245.

HachisukA, Y., KoJma, K. \& SATo, T. (1966). Fine filaments on the outside of the exosporium of Bacillus anthracis spores. J. Bact. 9r, 2382.

Hannay, C. L. (1956). Inclusions in bacteria. Symp. Soc. gen. Microbiol. 6, 318.

Holbert, P. E. (1960). An effective method of preparing sections of Bacillus polymyxa sporangia and spores for electron microscopy. J. cell. comp. Physiol. 7, 373.

Holt, S. C. \& Canale-Parola, E. (1967). Fine structure of Sarcina maxima and Sarcina ventriculi. J. Bact. 93, 399.

Holt, S. C. \& Leadbetter, E. R. (I967). Fine structure of Sporocytophaga myxococcoides. Arch. Microbiol. 57, 199.

KARNOVSKY, M. J. (196I). Simple methods for staining with lead at high pH in electron microscopy. J. cell. Biology II, 729.

Lechtman, M. D., Bartholomew, J. W., Phillips, A. \& Russo, M. (1965). Rapid methods of staining bacterial spores at room temperature. J. Bact. 89,848 .

Mrtchell, P. \& MoYle, J. (1956). Osmotic function and structure in bacteria. Symp. Soc. gen. Microbiol. 6, 150.

Murray, R. G. E. \& Birch-Anderson, A. (1963). Specialized structure in the region of the flagella tuft in Spirillum serpens. Can. J. Microbiol. 9, 393.

Robertson, J. D. (1959). The ultrastructure of cell membranes and their derivatives. Biochem. Soc. Symp. 16, 3.

RoBINow, C. F. (1960). Morphology of Bacterial Spores, their Development and Germination. In: The Bacteria. Vol. I. Structure. Ed. by I. C. Gunsalus and R. Y. Stanier. New York and London: Academic Press.

Salton, M. R. J. (1964). The Bacterial Cell Wall. Amsterdam: Elsevier Publishing Co.

Smith, N. R., Gordon, R. E. \& Clark, F. E. (1952). Aerobic sporeforming bacteria. U.S. Dep. Agric. Monograph, no. 16, Washington.

Warth, A. D., Ohye, D. F. \& MurRell, W. G. (1963). Location and composition of spore mucopeptide in Bacillus species. J. cell. Biology $16,593$.

Young, I. E. \& FITZ-JAMES, P. C. (1962). Chemical and morphological studies of bacterial spore formation. J. cell. Biology 12, I I5. 


\section{EXPLANATION OF PLATES}

(Unless otherwise indicated, the bar in each photograph represents $0.25 \mu$.)

Plate I

Fig. 1. Bacillus fastidiosus. Vegetative cell. Phase contrast.

Fig. 2. B. fastidiosus. Mature endospores. Phase contrast.

Fig. 3. B. fastidiosus. Chains of vegetative cells with mature endospores. Note cross-walls (arrows). Phase contrast.

\section{ELECTRON MICROGRAPHS}

Fig. 4. Bacillus fastidiosus. Vegetative cell. PTA-negatively stained preparation.

\section{Plate 2}

Fig. 5. Bacillus fastidiosus. Vegetative cell, negatively stained (PTA). Note flagellàr 'hook' (arrow) and fine structure of cell wall (CW).

Fig. 6. B. fastidiosus. Vegetative cell envelope after partial autolysis. PTA-negatively stained preparation.

Fig. 7. B. fastidiosus. Spore emerging from sporangium. Note (arrows) adhering vegetative cell envelope with periodic, apparently linear, fine structure. PTA-negatively stained preparation.

\section{Plate 3}

Fig. 8. Bacillus fastidiosus. Vegetative cell. Tangential thin section through outer cell surface.

Fig. 9. B. fastidiosus. Vegetative cell. Platinum-carbon shadowed preparation, $20^{\circ}$ angle.

\section{Plate 4}

Fig. Io. Bacillus fastidiosus. Free spore. Platinum-carbon shadowed preparation, $20^{\circ}$ angle.

Fig. I I. B. fastidiosus. Vegetative cell. Surface replica. Note fine structure (dotted lines).

Fig. I2. B. fastidiosus. Free spore. Surface replica. Polar knobs (single arrows) and possibly an equatorial ridge (double arrows) are seen.

\section{Plate 5}

Fig. I3. Bacillus fastidiosus. Vegetative cell. Thin section. $\mathrm{N}=$ nuclear material; $\mathrm{R}=$ ribosomes; $\mathbf{P M}=$ plasma membrane. Note layering in cell wall (SW).

Fig. 14. B. fastidiosus. Vegetative cells. Thin section. $\mathrm{N}=$ nuclear material; $\mathrm{M}=$ mesosome; $\mathrm{CW}=$ cell wall. Arrows indicate areas where possible cross-bridging is visible. The inset shows a connexion (arrow) between a mesosome (M) and plasma membrane.

Fig. I5. B. fastidiosus. Vegetative cell. Thin section.

Fig. 16. B. fastidiosus. Longitudinal thin section of vegetative cell with a developing endospore. $\mathbf{M}=$ mesosome; $\mathbf{N}=$ nuclear material $; \mathrm{CW}=$ cell wall $; \mathrm{Sp} . \mathrm{m} .=$ spore membranes; $\mathrm{IM}=$ inner forespore membrane; $\mathrm{OM}=$ outer forespore membrane; $\mathrm{IL}=$ intermediate layer; $\mathrm{Ex} .=\mathrm{exo}$ sporium; $\mathbf{P M}=$ plasma membrane. Arrows indicate continuity between plasma membrane and mesosomes.

\section{Plate 6}

Fig. 17. Bacillus fastidiosus. Developing spore. Longitudinal thin-section. Inner (IM) and outer spore membranes (SM) may be present. $\mathbf{C}_{2}=$ cortex; $\mathbf{P M}=$ plasma membrane; $\mathrm{VCW}=$ vegetative cell wall; $\mathbf{S C}=$ spore coats; $\mathrm{IM}=$ inner spore membrane; $\mathrm{OM}=$ outer spore membrane. Double arrows indicate developing exosporium.

Fig. 18. B. fastidiosus. Developing endospore. Transverse thin section. $\mathrm{SB}=$ spore body or core; $\mathrm{N}=$ nuclear region; $\mathbf{I M}=$ inner membrane; $\mathrm{Cl}_{1}=$ inner cortex; $\mathbf{C}_{2}=$ outer, less dense cortex; $\mathrm{OM}=$ outer membrane; $\mathrm{SC}=$ developing spore coats $; \mathrm{Ex} .=$ developing exosporium; $\mathrm{Sp} . \mathrm{G} .=$ vegetative cell wall or sporangium. 
Journal of General Microbiology, Vol. 52, No. 2

Plate I
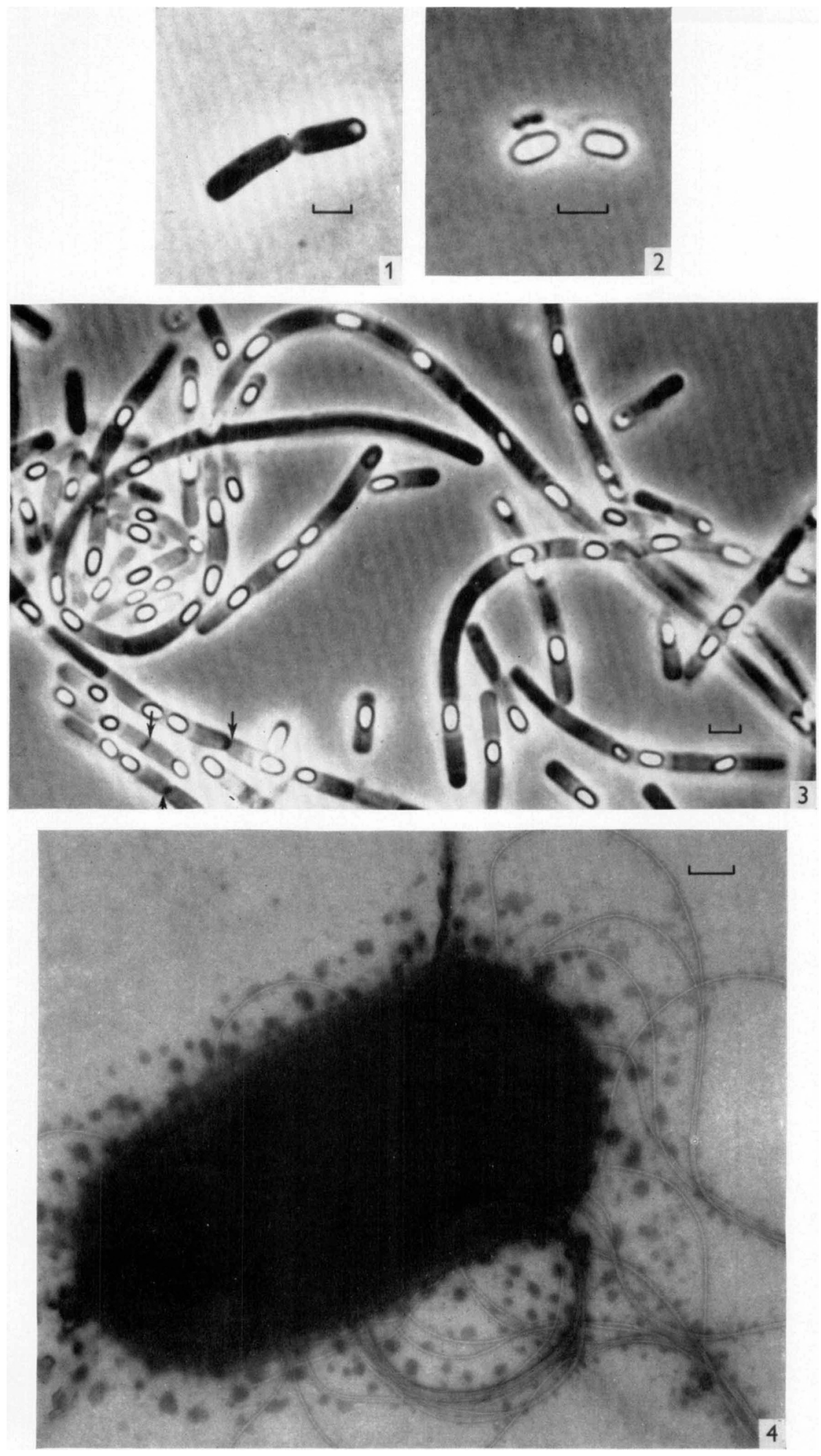

E. R. LEADBETTER AND S. C. HOLT 
Journal of General Microbiology, Vol. 52, No. 2

Plate 2
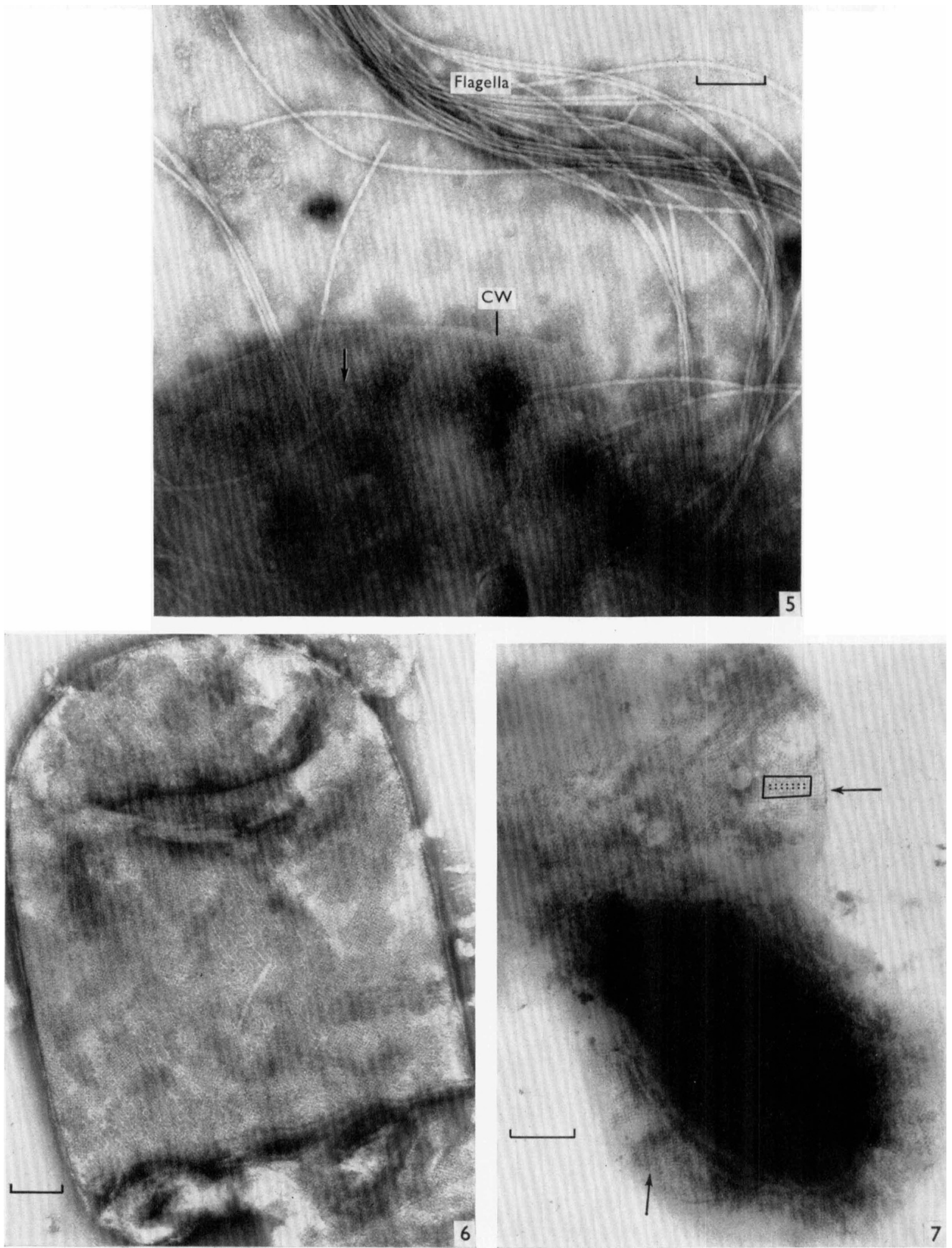

E. R. LEADBETTER AND S. C. HOLT 
Journal of General Microbiology, Vol. 52, No. 2

Plate 3
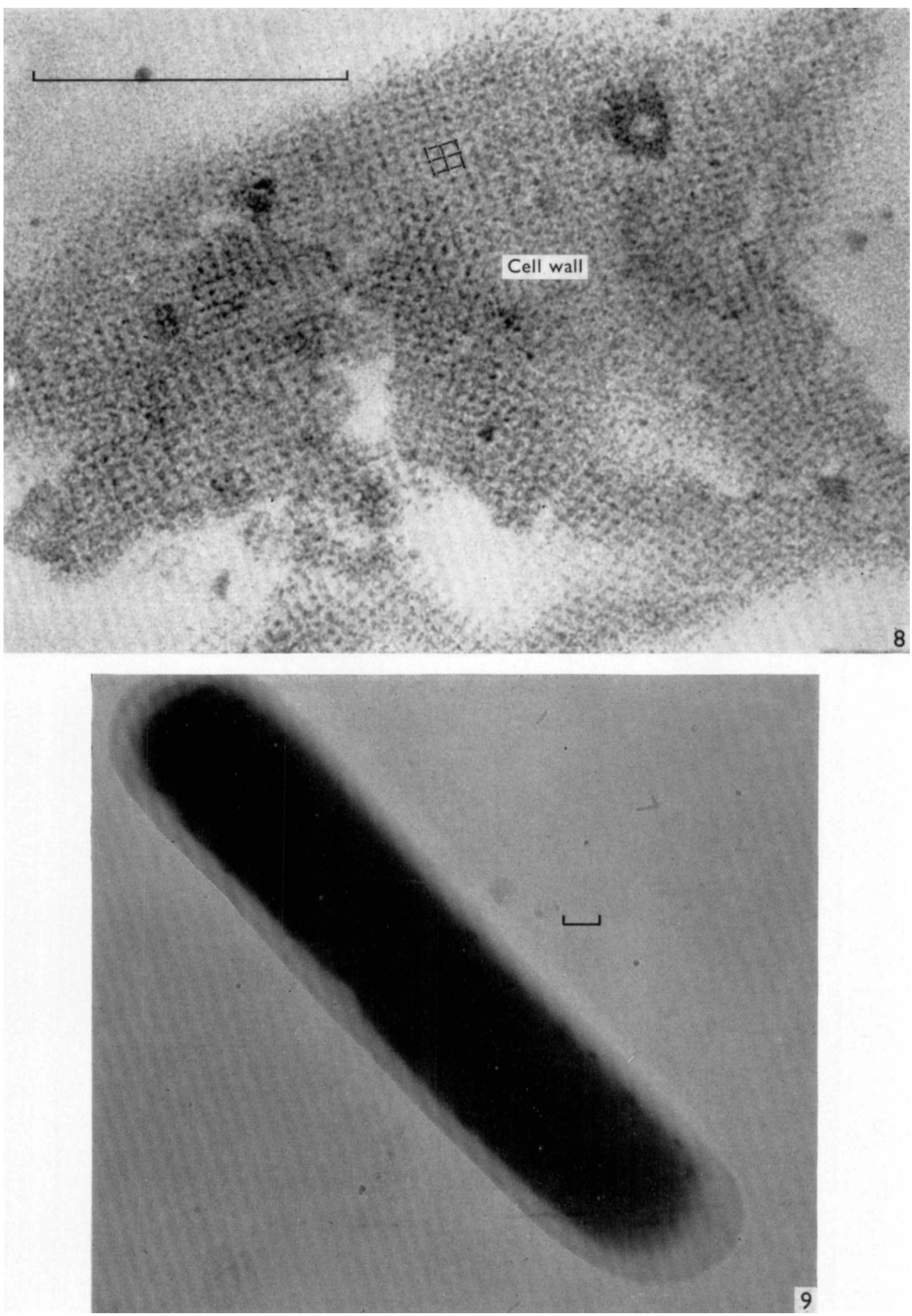

E. R. LEADBETTER AND S. C. HOLT 
Journal of General Microbiology, Vol. 52, No. 2

Plate 4
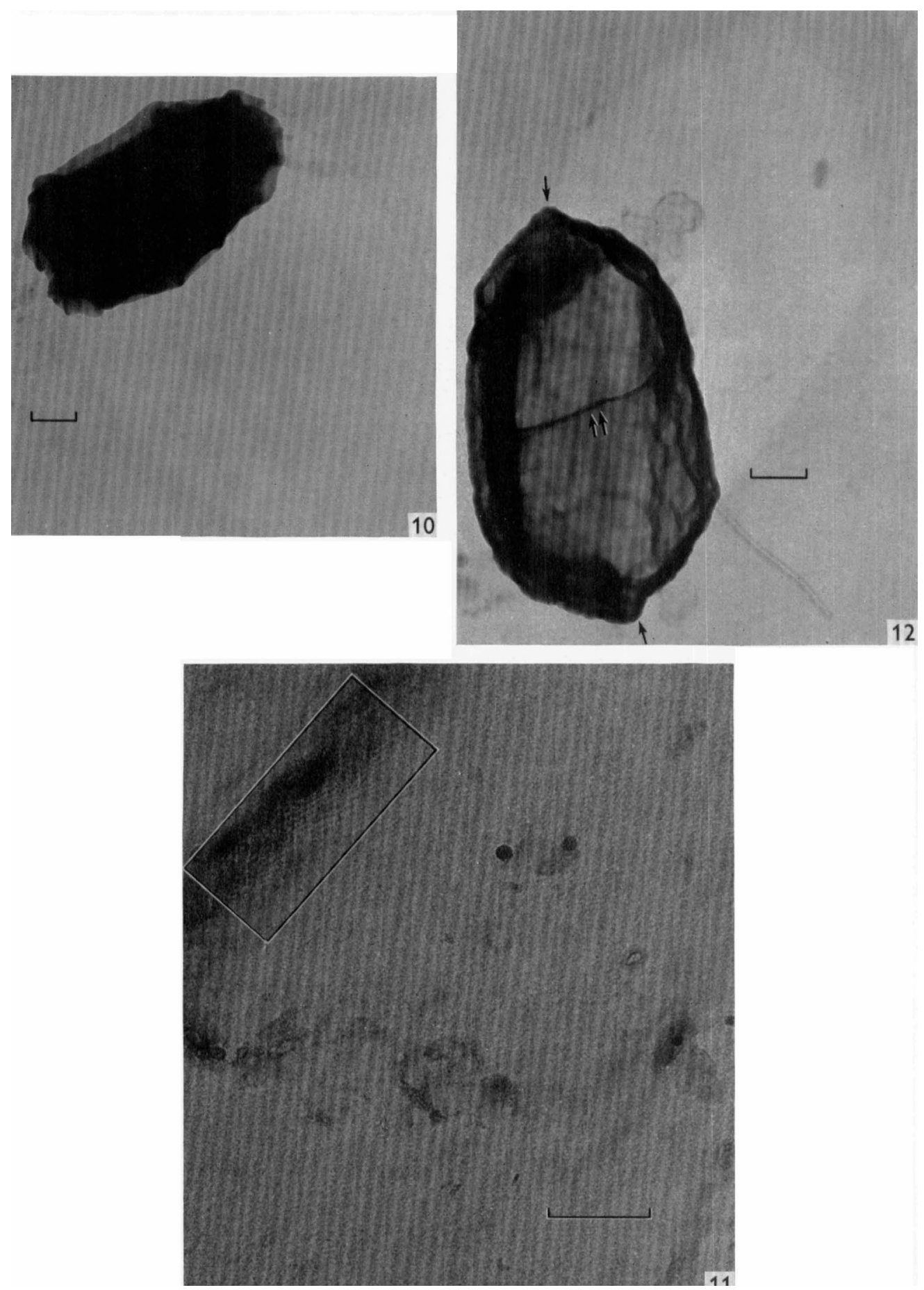

E. R. LEADBETTER AND S. C. HOLT 
Journal of General Microbiology, Vol. 52, No. 2

Plate 5
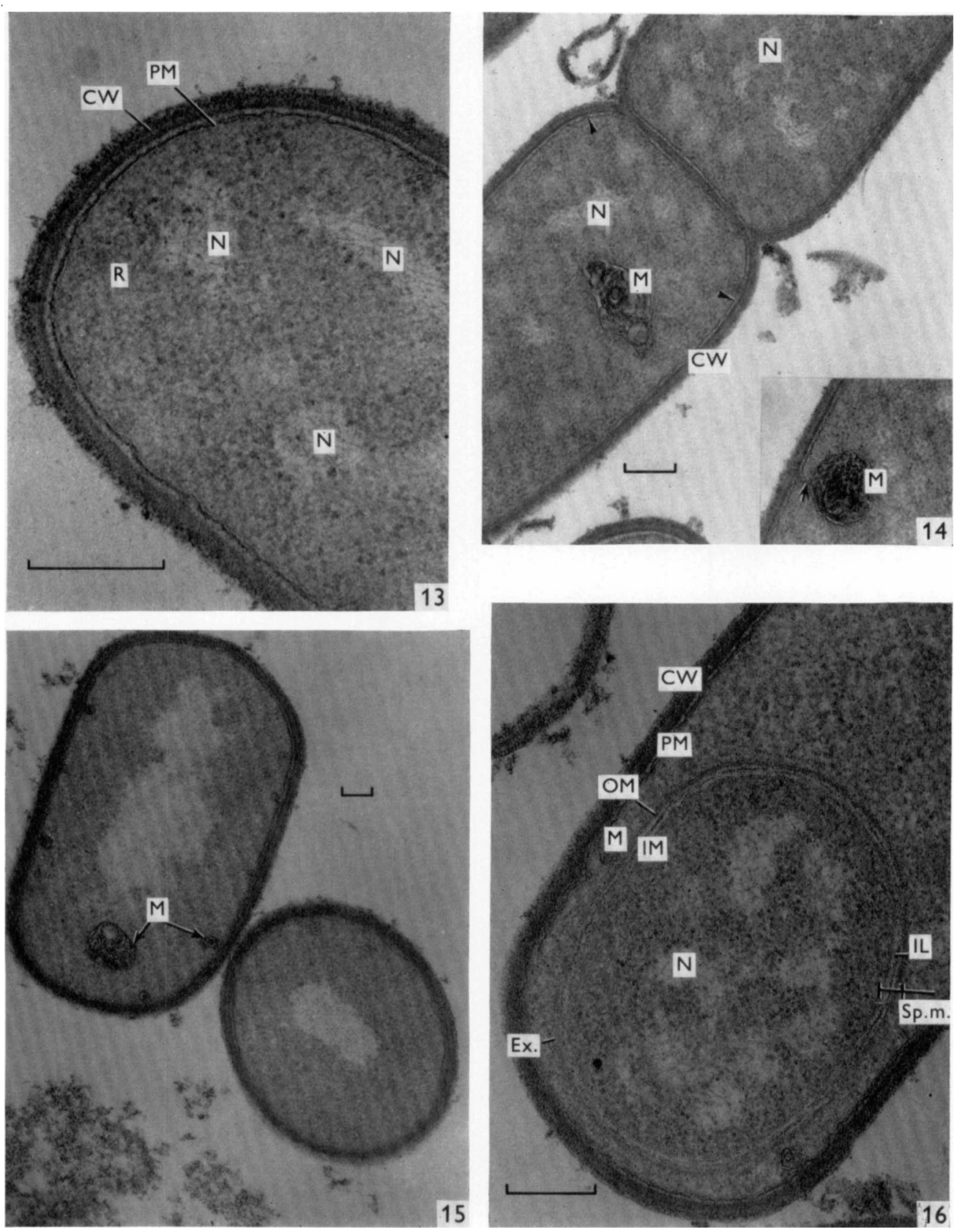

E. R. LEADBETTER AND S. C. HOLT 
Journal of General Microbiology, Vol. 52, No. 2

Plate 6
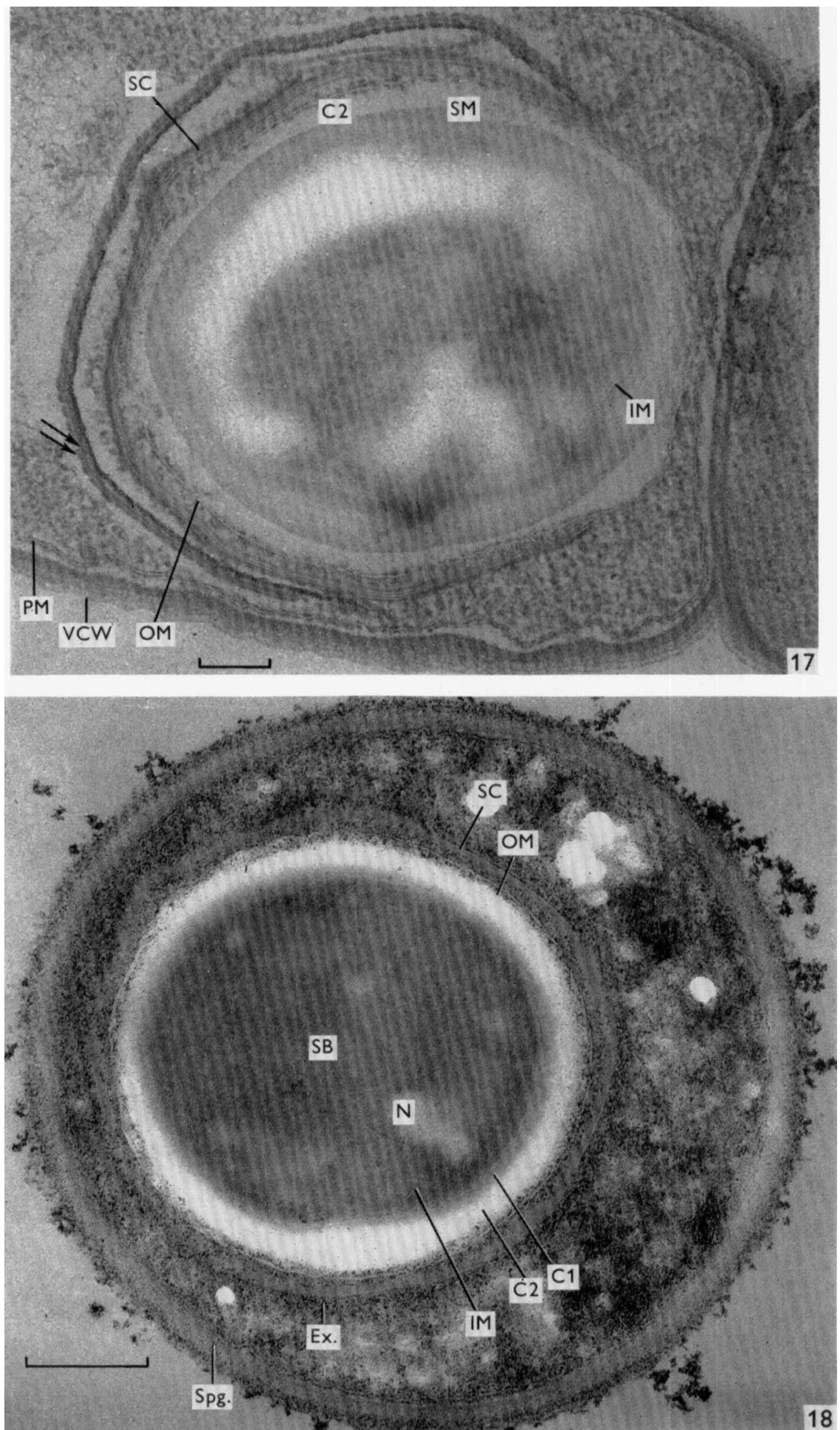

E. R. LEADBETTER AND S. C. HOLT 

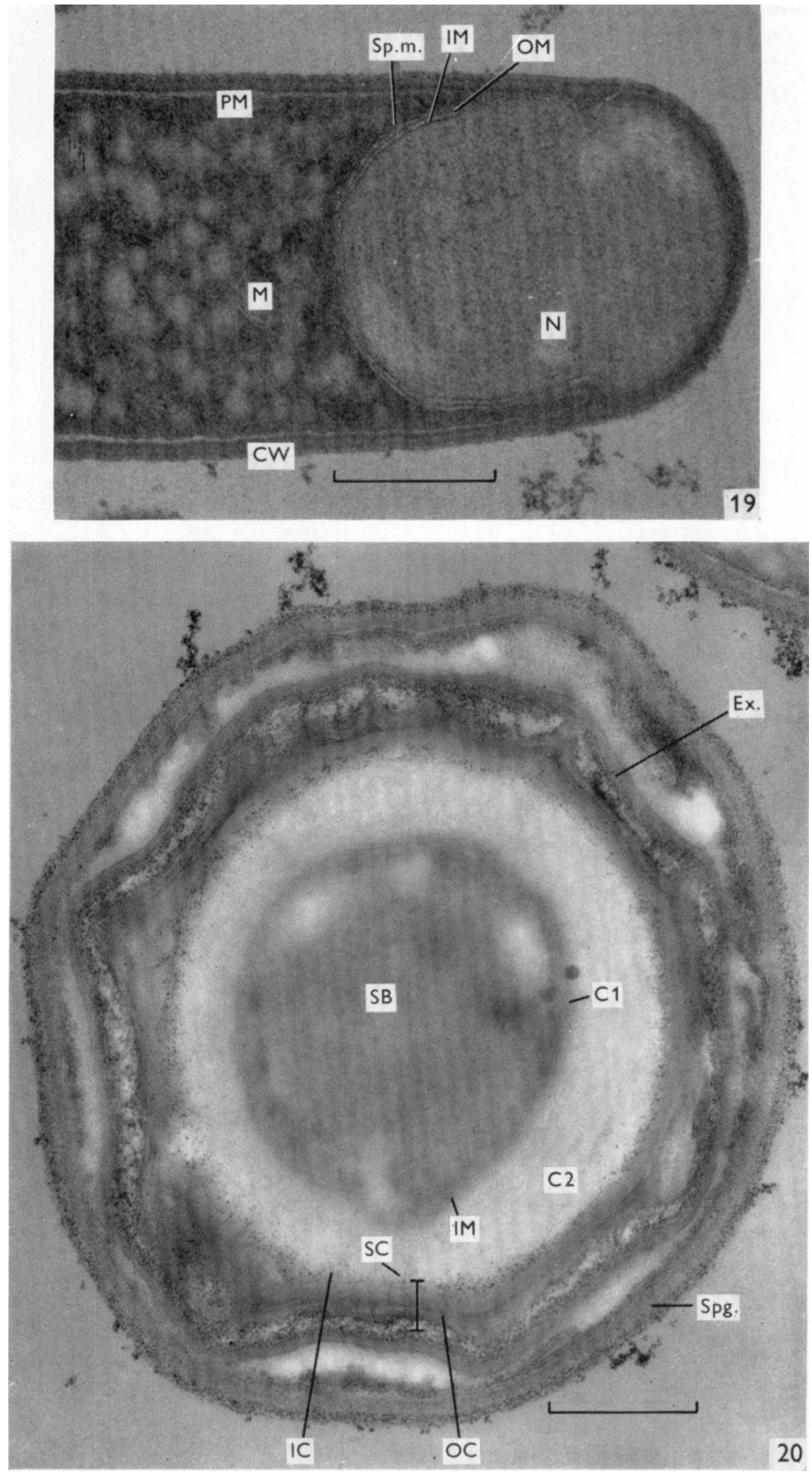

E. R. LEADBETTER AND S. C. HOLT 
Journal of General Microbiology, Vol. 52, No. 2

Plate 8
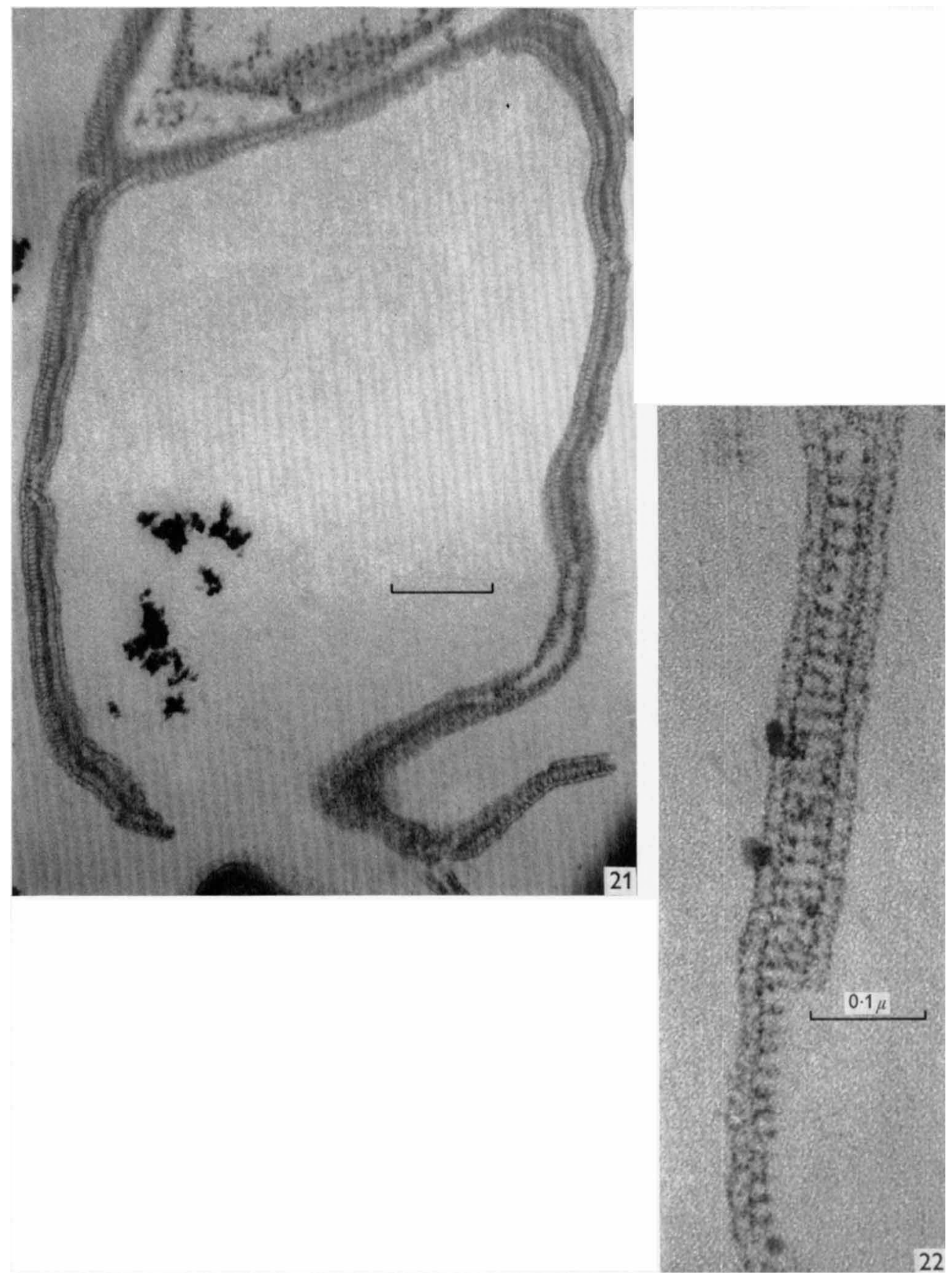

E. R. LEADBETTER AND S. C. HOLT 
Journal of General Microbiology, Vol. 52, No. 2

Plate 9
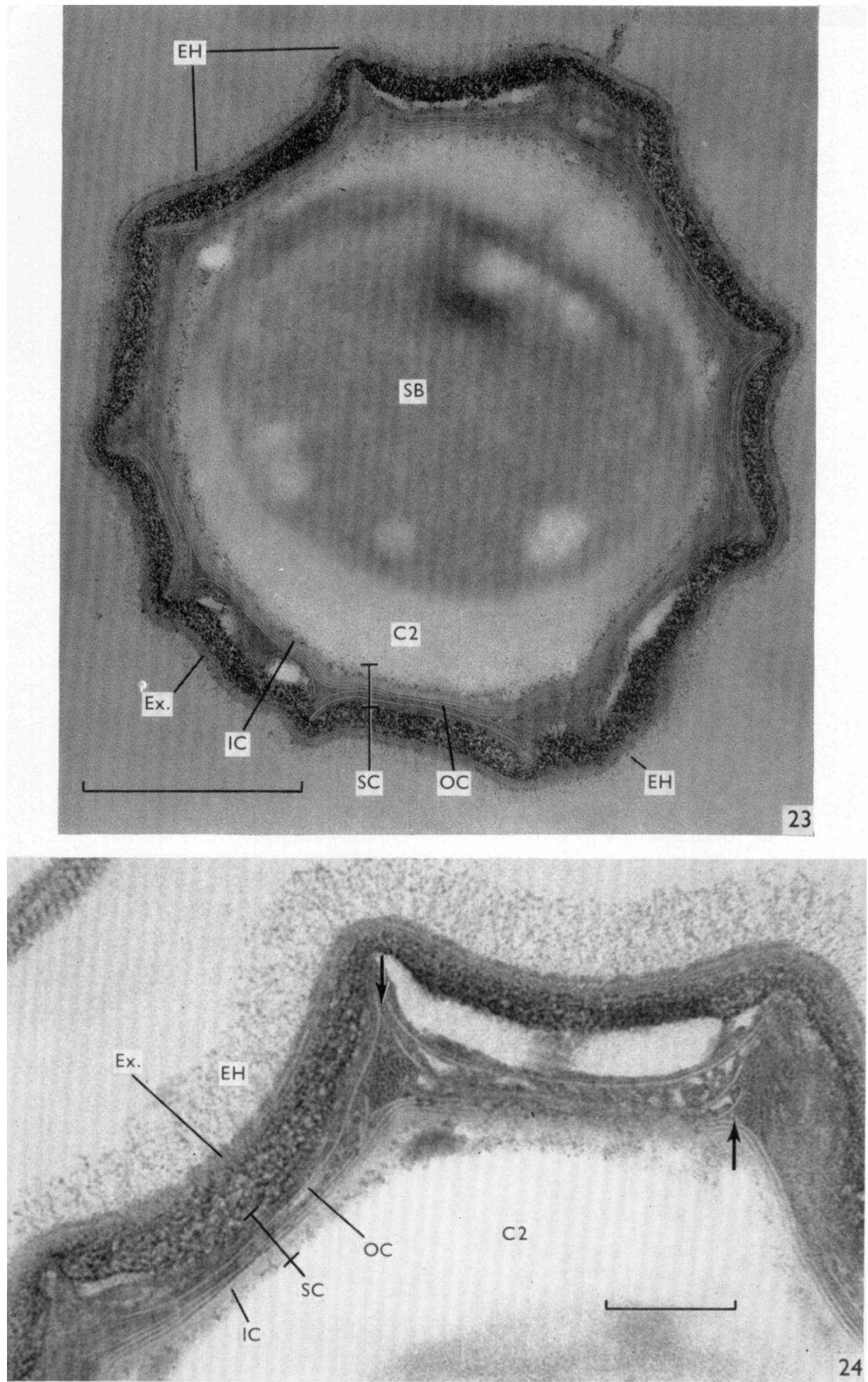

E. R. LEADBETTER AND S. C. HOLT 

Plate 7

Fig. I9. Bacillus fastidiosus. Developing endospore. Longitudinal thin section. IM = inner spore membrane; $\mathrm{OM}=$ outer spore membrane; Sp.m. = spore membranes; $\mathbf{M}=$ mesosome $\mathbf{P M}=$ plasma membrane; $\mathbf{N}=$ nuclear material $; \mathrm{CW}=$ vegetative cell wall. Arrow indicates continuity between plasma membrane and spore membranes.

Fig. 20. B. fastidiosus. Developing spore. Transverse thin section. $\mathrm{SB}=$ spore body or core $\mathrm{IM}=$ inner membrane; $\mathrm{C}_{1}=$ dense cortical area $\mathrm{C}_{2}=$ less dense cortical area; $\mathrm{SC}=$ spore coats, composed of inner (IC) and outer (OC) layers; Ex. = exosporium; Sp.g. = vegetative cell wall or sporangium.

\section{Plate 8}

Fig. 21. Bacillus fastidiosus. Vegetative cell wall and attached plasma membrane. Longitudinal thin section.

Fig. 22. B. fastidiosus. Portion of a fragmented vegetative cell wall and attached membranes.

\section{Plate 9}

Fig. 23. Bacillus fastidiosus. Free, mature spore. Transverse thin section. $\mathrm{SB}=$ spore body or core; $\mathrm{C}_{2}=$ diffuse outer cortex; $\mathrm{SC}=$ spore coats, composed of inner (IC) and outer (OC) layers; Ex. = exosporium; $\mathrm{EH}=$ exosporial hairs.

Fig. 24. B. fastidiosus. Free, mature spore. Transverse thin section. $\mathrm{C}_{2}=$ cortex; $\mathrm{SC}=$ spore coats, consisting of inner (IC) and outer (OC) layers; Ex. = exosporium; $\mathrm{EH}=$ exosporial hairs. Arrows indicate apices or projections formed by the spore coats. 